\title{
PENGARUH EXPERIENTIAL MARKETING TERHADAP LOYALITAS PELANGGAN PADA WAROENG STEAK AND SHAKE CABANG SISINGAMANGARAJA MEDAN
}

\author{
Siti Aisyah \\ Alumni Jurusan Manajemen Fakultas Ekonomi Universitas Negeri Medan \\ Riza Indriani \\ Dosen Jurusan Manajemen Fakultas Ekonomi Universitas Negeri Medan
}

\begin{abstract}
Abstrak
Penelitian ini bertujuan untuk menganalisis pengaruh tiap-tiap variabel pada experiential marketing, yaitu sense, feel, think, act, dan relate terhadap loyalitas pelanggan Waroeng Steak and Shake Cabang Sisingamangaraja Medan. Sampel sebanyak 96 orang responden dengan teknik pengambilan sampel yang digunakan adalah non probability sampling dengan teknik purposive sampling yaitu teknik pengambilan sampel dengan pertimbangan tertentu pelanggan yang sudah melakukan pembelian lebih dari satu kali. Analisis data menggunakan uji asumsi klasik, uji regresi linear berganda, uji hipotesis, dan uji determinasi $\left(R^{2}\right)$. Uji regresi linear berganda menunjukkan vaiabel yang terdapat dalam experiential marketing yaitu sense, feel, think, act, dan relate bernilai positif. Berdasarkan hasil uji hipotesis yaitu uji t, diketahui bahwa variabel yang termasuk dalam experiential marketing yaitu sense, feel, think, berpengaruh secara parsial dan signifikan terhadap loyalitas pelanggan. sedangkan act, dan relate berpengaruh secara parsial tetapi tidak signifikan terhadap loyalitas pelanggan pada Waroeng Steak and Shake Cabang Sisingamangaraja Medan. Hasil uji F sebesar 124,512 menunjukkan bahwa secara simultan atau serempak variabel yang termasuk dalam experiential marketing secara bersama-sama mempengaruhi variabel loyalitas pelanggan. Hasil $R^{2}$ menunjukkan bahwa $87,4 \%$ variabel independen sense, feel, think, act, dan relate mempengaruhi loyalitas pelanggan waroeng steak and shake cabang sisingamangaraja medan.
\end{abstract}

Kata kunci : Experiential Marketing, Sense, Feel, Think, Act, Relate, Loyalitas Pelanggan

\section{PENDAHULUAN}

Perkembangan dunia usaha semakin hari semakin pesat, setiap pemimpin perusahaan ingin perusahaannya yang terbaik diantara pesaingnya -pesaingnya. Demikian juga dengan dunia pemasaran, perkembangannya semakin pesat dan telah menciptakan strategi-strategi baru dalam mempertahankan maupun mendapatkan pelanggan baru. Strategi-strategi tersebut mengharuskan perusahaan beralih dari pendekatan pemasaran tradisional ke pendekatan yang lebih sesuai. Pendekatan produk sudah tidak tepat diterapkan, perusahaan harus lebih menekankan pada konsumen. Konsumen menginginkan produk dan kampanye pemasaran yang menggugah selera, menyentuh hati dan menstimulasi pikiran mereka, serta komunikasi pemasaran yang menawarkan suatu pengalaman yang berbeda dari lainnya.

Maraknya bisnis rumah makan pada saat ini menjadikan persaingan yang semakin sengit di industri makanan untuk merebut perhatian konsumen dan loyalitas konsumen. Perusahaan harus menciptakan strategi pemasaran yang memberi 
kesan mendalam di benak konsumen. Loyalitas konsumen menjadi masalah setiap perusahaan, setiap perusahaan dituntut untuk memberikan produk dan pelayanan yang terbaik agar konsumen merasa puas dan akhirnya loyal.

Loyalitas menunjukkan kecenderungan pelanggan untuk menggunakan suatu produk barang atau jasa dengan tingkat konsistensi yang tinggi, dimana suatu produk merupakan respon perilaku atau pembelian yang bersifat bias dan terungkap secara terus menerus oleh pengambil keputusan dengan memperhatikan satu atau lebih alternatif dari sejumlah alternatif dan merupakan fungsi proses psikologis (Bahar dkk dalam Semadi, 2012). Pada industri makanan pun demikian, dalam persaingan yang ketat banyak pilihan rumah makan bagi konsumen. Oleh karena itu loyalitas mutlak dipertimbangkan setiap perusahaan pada saat ini.

Pelanggan rumah makan menjadi objek penelitian ini, dimana rumah makan merupakan produsen yang menawarkan makanan dan minuman disertai dengan nilai tambah berupa pelayanan dan suasana yang muncul dari penataan interior kepada pelanggan. Bisnis rumah makan merupakan salah satu bidang usaha yang masih bisa bertahan dan bahkan berkembang di dalam kondisi perekonomian yang tidak stabil. Alasan mendasar bagi para pebisnis rumah makan adalah orang perlu hidup untuk makan sehingga ini menjadi alasan kuat berkembangnya bisnis ini.

Salah satu pendekatan pemasaran yang menciptakan kesan yang mendalam di benak konsumen yaitu dengan menciptakan pengalaman yang unik. Konsep pemasaran yang menciptakan pengalaman unik kepada pelanggan sudah dikenal dengan istilah experiential marketing. Konsep ini berusaha menghadirkan pengalaman yang unik, positif dan mengesankan kepada konsumen melalui lima strategi yaitu sense, feel, think, act, dan relate.

Sense (panca indera) muncul untuk menciptakan pengalaman panca indera melalui mata, mulut, kulit, lidah, hidung. Feel (perasaan) muncul untuk menyentuh perasaan terdalam dan emosi pelanggan dengan tujuan menciptakan pengalaman yang efektif. Think (cara pikir) bertujuan untuk menciptakan kognitif, pemecahan masalah yang mengajak konsumen untuk berpikir kreatif. Act (kebiasaan) bertujuan untuk mempengaruhi perilaku, gaya hidup, dan interaksi dengan konsumen. Relate (hubungan) yang digunakan untuk mempengaruhi konsumen dan menggabungkan seluruh aspek sense, feel, think, dan act serta menitik beratkan pada persepsi positif dimata konsumen.

Dorongan untuk menjadi yang terunik dengan memberikan sentuhan experiential marketing (pengalaman yang mengesankan) dalam setiap proses pemasaran semakin menguat. Hal tersebut tidak mudah karena situasi persaingan produk yang semakin kompetitif dan pilihan media untuk beriklan yang semakin luas, mendorong para pemasar untuk mencari inovasi baru agar dapat menghasilkan produk yang unik dan tidak dapat ditiru oleh pesaing sehingga lebih baik mengadakan pendekatan pada sensori pelanggan 
dari pada rasio pelanggan. Sensori yang terdapat dalam sense, feel, think, act, dan relate, diyakini akan lebih efektif bagi pelanggan (Schmitt dalam Kustini, 2007), karena sensori yang terdapat dalam sense, feel, think, act, dan relate dapat memberikan pengalaman jiwa yang luar biasa. Pelanggan tidak hanya tertarik pada fungsi produk atau jasa, melainkan lebih dalam lagi yaitu pengalaman jiwa yang masuk kedalam produk atau jasa tersebut.

\section{Experiential}

marketing

memberikan peluang pada pelanggan untuk memperoleh serangkaian pengalaman atas merek produk dan jasa yang memberikan cukup informasi untuk melakukan keputusan pembelian. Aspek emosional dan rasional adalah beberapa aspek yang hendak dibidik pemasar melalui program ini dan seringkali kedua aspek ini memberikan efek luar biasa dalam pemasaran, terutama kepuasan dan loyalitas pelanggan (Andreani, 2007).

Experiential marketing bertujuan untuk meningkatkan loyalitas jangka panjang dan juga mengikat konsumen dengan memberikan pengalaman yang tak terlupakan ketika menikmati produk dari perusahaan tersebut. Pengalaman yang dirasakan konsumen akan menentukan loyalitas konsumen, karena loyalitas konsumen tidak terbentuk dalam waktu singkat tetapi melalui pengalaman konsumen itu sendiri dari pembelian konsisten sepanjang waktu. Bila yang didapat sudah sesuai dengan harapan dari pengalaman yang dirasakan konsumen, maka proses pembelian terus berulang. Hal ini dapat dikatakan bahwa telah timbul loyalitas konsumen pada suatu produk karena pengalaman yang didapat konsumen sesuai dengan yang dinginkan. Tetapi jika pengalaman yang didapat konsumen dari mengkonsumsi suatu produk tidak sesuai dengan apa yang diharapkan atau konsumen tidak puas maka konsumen tidak akan berhenti untuk mencoba produk-produk lain. Sehingga hal ini menyebabkan konsumen tidak loyal karena pengalaman yang dirasakan ketika mengkonsumsi suatu produk tidak sesuai dengan yang diinginkan.

Melalui experiential marketing pemasar berusaha untuk mengerti, berinteraksi dengan konsumen dan berempati terhadap kebutuhan mereka. Dengan strategi ini diharapkan konsumen akan menjadi loyal, bersedia melakukan hubungan jangka panjang, menggunakan produk dan jasa perusahaan secara terus menerus dan merekomendasikannya kepada temanteman dan orang terdekat mereka (Kusumawati, 2011).

Pada tahun 2002 banyak produsen menggunakan experiential marketing dalam memasarkan produknya (http://www.reindo.co.id) karena para produsen telah sadar bahwa dalam memasarkan produknya bukan hanya menjual produk yang bagus tetapi juga harus membuat pelanggan merasakan emosi yang mendalam dengan produk yang dijual sehingga terjadi hubungan emosi antara pelanggan dan produk yang dijual.

Sebagai salah satu jenis usaha yang bergerak dalam bidang rumah makan, Waroeng Steak and Shake tidak lepas dari persaingan bisnis yang semakin ketat. Dengan adanya persaingan yang semakin ketat dalam 
jenis usaha rumah makan tersebut, maka berbagai upaya dilakukan Waroeng Steak and Shake dengan keunikan menu dan pelayanannya agar pelanggan mendapatkan pengalaman yang tidak biasa ketika membeli produk-produk Waroeng Steak and Shake. Waroeng Steak and Shake pertama kali dibuka di Yogyakarta dan sekarang sudah memiliki 69 gerai di berbagai kota besar di Indonesia seperti Jakarta, Surabaya, Semarang, Bandung, Malang, Denpasar Bali, dan Medan. Umumnya gerai Waroeng Steak and Shake berada di sekitar lokasi kampus yang banyak mahasiswa. Pada bagian depan tempat makan ini ada tulisan "Waroeng Steak \& Shake" dengan paduan warna kuning dan hitam. Sehingga hal ini memberikan ciri khas pada Waroeng Steak and Shake dan memberikan kesan kepada konsumen dan mengingatkan konsumen tentang ciri dari Waroeng Steak and Shake. Pelayanan di Waroeng Steak and Shake termasuk sangat bagus, semua tamu akan di layani dengan senyum ramah. Pesanan akan tiba di meja makan dalam waktu relatif singkat. Harga yang ditawarkan oleh Waroeng Steak and Shake relatif murah sehingga terjangkau oleh setiap kalangan.

Waroeng Steak and Shake yang ada di Medan Sumatera Utara juga memiliki manajemen, jenis, menu, layout yang sesuai dengan yang ditentukan oleh Waroeng Steak and Shake pusat yang ada di Yogyakarta. Waroeng Steak and Shake yang ada di Medan memiliki tiga cabang yaitu berada di Jl. Adam Malik, Jl. Dr. Mansyur, dan Jl. Sisingamangaraja. Lokasi Waroeng Steak and Shake yang mudah diakses dan luasnya lapangan parkir yang tersedia baik bagi pengendara sepeda motor maupun mobil.

Sebagai salah satu cabang Waroeng Steak and Shake yang berada di Medan, Waroeng Steak and Shake cabang Sisingamangaraja Medan harus memberikan pengalaman yang unik dan mengesankan. Apabila konsumen merasa nyaman, puas terhadap produk yang ditawarkan, dan pelayanan yang diberikan sangat baik di Waroeng Steak and Shake cabang Sisingamangaraja Medan maka konsumen akan melakukan pembelian kembali. Sebaliknya, apabila konsumen merasa tidak nyaman, tidak puas terhadap produk yang ditawarkan, dan pelayanan yang diberikan tidak baik maka konsumen akan berhenti melakukan pembelian di Waroeng Steak and Shake cabang Sisingamangaraja Medan karena pengalaman yang mereka rasakan tidak enak. Pengalaman baik dan buruk yang konsumen dapatkan akan mempengaruhi loyalitas pelanggan Waroeng Steak and Shake cabang Sisingamangaraja Medan.

\section{METODE PENELITIAN \\ Lokasi Penelitian}

Penelitian ini dilakukan di Waroeng Steak and Shake yang terletak di jalan Sisingamangaraja No. 314, Medan.

\section{Populasi dan Sampel \\ Populasi}

Populasi dalam penelitian ini adalah semua konsumen yang membeli dan makan di Waroeng Steak and Shake yang terletak di jalan Sisingamangaraja No. 314, Medan. 
Populasi Waroeng Steak and Shake cabang Sisingamangaraja Medan ini termasuk jenis populasi yang tidak terbatas, karena konsumen yang datang jumlahnya berbeda setiap hari. Pupulasi tidak terbatas adalah suatu populasi yang mengalami proses secara terus menerus sehingga ukuran $\mathrm{N}$ (jumlah populasi) menjadi tidak terbatas (Suharyadi dan Purwanto, $2004: 323)$.

\section{Sampel}

Metode pengambilan sampel yang digunakan adalah non probability sampling, dengan teknik purposive sampling. Teknik purposive sampling yaitu teknik penentuan sampel dengan pertimbangan tertentu ( Sugiono, 2012 :122). Pertimbangan yang ditetapkan dalam penelitian ini adalah pelanggan Waroeng Steak and Shake yang sudah melakukan pembelian lebih dari satu kali.

Dalam menentukan sampel menurut Purba (1996) dengan menggunakan rumus sebagai berikut :

$$
n=\frac{z^{2}}{4(m o e)^{2}}
$$

Dimana :

$$
\begin{aligned}
& \mathrm{n}=\text { Jumlah sampel } \\
& \mathrm{Z}=\begin{array}{l}
\text { Tingkat keyakinan yang } \\
\text { dibutuhkan } \\
\text { penelitian sampel } \\
1,96 \%=
\end{array}
\end{aligned}
$$

Moe = Margin of error atau kesalahan yang bisa ditoleransi sebesar $10 \%$

Berdasarkan rumus diatas, maka diperoleh jumlah sampel sebagai berikut :

$$
\begin{aligned}
n & =\frac{1,96^{2}}{4(0,1)^{2}} \\
& =96,04
\end{aligned}
$$

Berdasarkan rumus maka sampel yang diperoleh sebesar 96,04 orang, sehingga dibulatkan menjadi 96 orang.

\section{Variabel Penelitian dan Defenisi Operasional \\ Variabel Penelitian}

1. Variabel bebas $\left(\mathrm{X}_{1}\right)$ yaitu sense

2. Variabel bebas $\left(\mathrm{X}_{2}\right)$ yaitu feel

3. Variabel bebas $\left(\mathrm{X}_{3}\right)$ yaitu think

4. Variabel bebas $\left(\mathrm{X}_{4}\right)$ yaitu act

5. Variabel bebas $\left(\mathrm{X}_{5}\right)$ yaitu relate

6. Variabel terikat $(\mathrm{Y})$ yaitu loyalitas pelanggan

\section{Defenisi Operasional}

a. Sense $\left(\mathrm{X}_{1}\right)$ yaitu panca indera yang didapat pelanggan melalui pengalamannya.

Indikator sense yaitu :

- Aroma produk

- Rasa produk

- Penataan ruangan

- Musik yang diperdengarkan

- Pencahayaan ruangan

b. Fell $\left(\mathrm{X}_{2}\right)$ yaitu perhatianperhatian kecil yang ditujukan pada konsumen dengan tujuan untuk menyentuh perasaan dan emosi pelanggan Indikator fell yaitu :

- Image produk

- Konsep produk

- Kesan produk

c. Think $\left(\mathrm{X}_{3}\right)$ yaitu mendorong pelanggan menggunakan pikirannya secara kreatif dengan menilai lebih baik akan produk yang di beli dan 
mengingat bagaimana produk tersebut.

Indikator think yaitu :

- Keadaan ruangan

- Sikap karyawan

- Inovasi baru nama-nama produk

d. Act $\left(\mathrm{X}_{4}\right)$ yaitu menciptakan pengalaman konsumen dalam hubungannya dengan physical body, lifestyle, dan interaksi dengan orang lain.

Indikator act yaitu :

- Sistem pembayaran

- Pelayanan

e. Relate $\left(\mathrm{X}_{5}\right)$ yaitu apabila pelanggan sudah percaya terhadap produk maka pelanggan akan menceritakan pengalaman yang didapat dari membeli produk kepada lingkungan dan merekomendasikan.

Indikator relate yaitu :

- Menceritakan pengalaman kepada orang lain

- Memberikan rekomendasi kepada orang lain

f. Loyalitas pelanggan (Y) yaitu komitmen untuk bertahan secara mendalam untuk melakukan pembelian ulang atau berlangganan kembali produk atau jasa terpilih secara konsisten dimasa yang akan datang, meskipun pengaruh situasi-situasi dan usaha-usaha pemasaran mempunyai potensi untuk menyebabkan perubahan perilaku.

Indikator loyalitas pelanggan yaitu :

- Melakukan pembelian secara teratur

- Membeli antar lini produk
- Merekomendasikan kepada orang lain

- Kebal terhadap daya tarik pesaing

\section{Uji Regresi Linear Berganda}

Untuk mengetahui besarnya

pengaruh yang ditimbulkan oleh variabel independen yaitu sense $\left(\mathrm{X}_{1}\right)$, fell $\left(\mathrm{X}_{2}\right)$, think $\left(\mathrm{X}_{3}\right)$, act $\left(\mathrm{X}_{4}\right)$, dan relate $\left(\mathrm{X}_{5}\right)$ terhadap variabel dependen yaitu loyalitas pelanggan (Y) dengan menggunakan teknik Analisis Linear Berganda ( Ghozali, $2005: 84$ ).

Persamaan regresi linear berganda yang dipakai adalah sebagai berikut :

$$
\begin{gathered}
Y=a+b_{1} X_{1}+b_{2} X_{2}+b_{3} X_{3}+b_{4} X_{4}+ \\
b_{5} X_{5}+e
\end{gathered}
$$

Keterangan :

$\mathrm{Y}=$ Loyalitas pelanggan

a = nilai konstan

$b_{1}-b_{5}=$ Koefisien regresi

$\mathrm{X}_{1} \quad=$ variabel sense

$\mathrm{X}_{2} \quad=$ variabel $\mathrm{fell}$

$\mathrm{X}_{3} \quad=$ variabel think

$\mathrm{X}_{4}=$ variabel $a c t$

$\mathrm{X}_{5}=$ variabel relate

e $\quad=$ standar error

Uji Hipotesis

Uji t ( parsial )

Uji t dilakukan untuk mengetahui seberapa besar variabel independen (X) yaitu sense, feel, think, act,dan relate mempengaruhi variabel dependen (Y) yaitu loyalitas pelanggan. Untuk menguji secara parsial maka digunakan uji t yaitu membandingkan $t$ hitung dengan $t$ tabel.

Kriteria pengambilan keputusannya adalah sebagai berikut : 
- Jika $t_{\text {hitung }}>t_{\text {tabel }}$ pada taraf kepercayaan $95 \%$ atau $\alpha=5 \%$ maka hipotesis dalam penelitian ini diterima.

- Jika $t_{\text {hitung }}<\mathrm{t}_{\text {tabel }}$ pada taraf kepercayaan $95 \%$ atau $\alpha=5 \%$ maka hipotesis dalam penelitian ini ditolak.

\section{Uji F (Simultan)}

Uji $F$ pada dasarnya menunjukkan apakah semua variabel independen (X) secara bersama-sama dapat berpengaruh terhadap variabel dependen (Y) (Ghojali, 2005:84). Dimana $F_{\text {hitung }}>F_{\text {tabel, }}$ maka hipotesis dalam inipenelitian diterima atau secara bersama-sama variabel bebas dapat menerangkan variabel terikat secara serentak. Sebaliknya apabila $\mathrm{F}_{\text {hitung }}<\mathrm{F}_{\text {tabel, }}$ maka hipotesis dalam penelitian ini ditolak atau secara bersama-sama variabel bebas tidak memiliki pengaruh pada variabel terikat. Untuk mengetahui signifikan secara bersama-sama variabel bebas terhadap variabel terikat maka digunakan probability sebesar $5 \%(\alpha$ $=0,05)$ pada taraf kepercayaan $95 \%$.

\section{Koefisien Determinasi $\left(\mathbf{R}^{2}\right)$}

Analisis determinasi $\left(\mathrm{R}^{2}\right)$ digunakan untuk mengukur besarnya kontribusi persentase sumbangan variabel bebas sense, fell, think, act, dan relate $\left(\mathrm{X}_{1}, \mathrm{X}_{2}, \mathrm{X}_{3}, \mathrm{X}_{4}, \mathrm{X}_{5}\right)$ terhadap variabel terikat yaitu loyalitas pelanggan (Y) secara bersama-sama dimana $0 \leq \mathrm{R}^{2} \leq 1$. Hal ini berarti nilai $r^{2}$ adalah 1 atau mendekati. Maka semakin kuat pengaruh variabel bebas terhadap variabel terikat. Sebaliknya, apabila nilai $\mathrm{R}^{2}$ mendekati 0 , maka lemah pengaruh variabel bebas terhadap variabel terikat.

\section{HASIL PENELITIAN DAN \\ PEMBAHASAN \\ Hasil Penelitian \\ Uji Regresi Linear Berganda}

Persamaan regresi berganda yang dipakai untuk menentukan koefisien regresi yaitu $\mathrm{Y}=\mathrm{a}+\mathrm{b}_{1} \mathrm{X}_{1}+\mathrm{b}_{2} \mathrm{X}_{2}+$ $\mathrm{b}_{3} \mathrm{X}_{3}+\mathrm{b}_{4} \mathrm{X}_{4}+\mathrm{b}_{5} \mathrm{X}_{5}+\mathrm{e}$.

Tabel 1. Hasil Perhitungan Analisis Regresi Berganda

Coefficients $^{\mathrm{a}}$

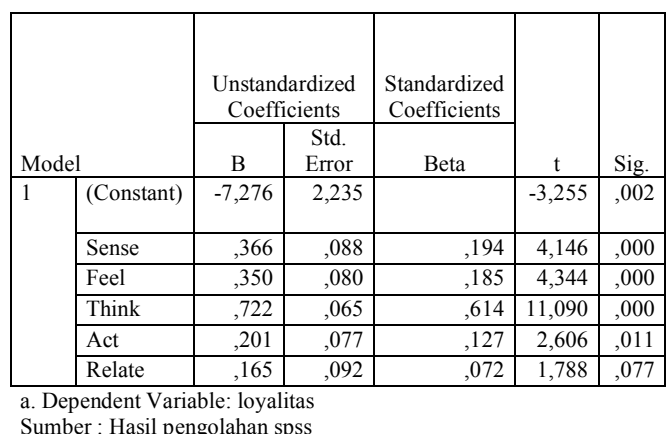

Dari hasil pengolahan data SPSS

diatas dapat dijelaskan sebagai berikut :

$\mathrm{Y}=-7,276+0,366 \mathrm{X}_{1}+0,350 \mathrm{X}_{2}+$ $0,722 \mathrm{X}_{3}+0,201 \mathrm{X}_{4}+0,165 \mathrm{X}_{5}+\mathrm{e}$.

Nilai masing - masing koefisien 
regresi variabel independen dari model regresi linear tersebut memberikan gambaran bahwa :

1. Konstanta sebesar $-7,276$ menyatakan bahwa jika tidak ada variabel $\mathrm{X}$ maka loyalitas adalah sebesar -7,276.

2. Koefisien regresi variabel sense $\left(\mathrm{X}_{1}\right)$ sebesar 0,366 menggambarkan bahwa setiap terjadi perubahan sense sebesar satu satuan maka akan mempengaruhi loyalitas sebesar 0,366 (asumsi faktor lain konstan).

3. Koefisien regresi variabel feel $\left(\mathrm{X}_{2}\right) \quad$ sebesar $\quad 0,350$ menggambarkan bahwa setiap terjadi perubahan feel sebesar satu satuan maka akan mempengaruhi loyalitas sebesar 0,350 (asumsi faktor lain konstan).

4. Koefisien regresi variabel think $\left(\mathrm{X}_{3}\right)$ sebesar 0,722 menggambarkan bahwa setiap terjadi perubahan think sebesar satu satuan maka akan mempengaruhi loyalitas sebesar 0,722 (asumsi faktor lain konstan)

5. Koefisien regresi variabel act $\left(\mathrm{X}_{4}\right)$ sebesar 0,201 menggambarkan bahwa setiap terjadi perubahan act sebesar satu satuan maka akan mempengaruhi loyalitas sebesar 0,201 (asumsi faktor lain konstan)

6. Koefisien regresi variabel relate $\left(\mathrm{X}_{5}\right)$ sebesar 0,165 menggambarkan bahwa setiap terjadi perubahan relate sebesar satu satuan maka akan mempengaruhi loyalitas sebesar 0,165 (asumsi faktor lain konstan)

\section{Uji Hipotesis}

Uji t (parsial)

Uji t dilakukan untuk mengetahui seberapa besar variabel independen (X) yaitu sense, fell, think, act,dan relate mempengaruhi variabel dependen (Y) yaitu loyalitas pelanggan. Untuk menguji secara parsial maka digunakan uji t yaitu membandingkan $t$ hitung dengan $t$ tabel.

Kriteria pengambilan keputusannya adalah sebagai berikut :

$\circ \quad$ Jika $t_{\text {hitung }}>t_{\text {tabel }}$ pada taraf kepercayaan $95 \%$ atau $\alpha=$ $5 \%$ maka hipotesis dalam penelitian ini diterima.

- Jika $t_{\text {hitung }}<t_{\text {tabel }}$ pada taraf kepercayaan $95 \%$ atau $\alpha=$ 5\% maka hipotesis dalam penelitian ini ditolak. 
Berdasarkan tabel. 1 diatas dengan membandingkan nilai $t$ hitung dengan $t$ tabel maka dapat disimpulkan:

1. Nilai $t_{\text {hitung }}$ variabel sense yaitu 4,146 dan $t_{\text {tabel }}$ bernilai 1,661 sehingga $t_{\text {hitung }}>t_{\text {tabel }}$ ( $4,146>1,661)$. Ini menunjukkan bahwa hipotesis diterima yaitu variabel sense berpengaruh secara parsial terhadap loyalitas pelanggan. Secara signifikan variabel sense juga berpengaruh terhadap loyalitas pelanggan karena nilai sig lebih kecil dari 0,05 ( $0,000<0,05)$. Sehingga dapat disimpulkan bahwa variabel sense berpengaruh secara parsial dan signifikan terhadap loyalitas pelanggan

2. Nilai $t_{\text {hitung }}$ variabel feel yaitu 4,344 dan $t_{\text {tabel }}$ bernilai 1,661 sehingga $t_{\text {hitung }}>t_{\text {tabel }}(4,344$ $>1,661)$. Ini menunjukkan bahwa hipotesis diterima yaitu variabel feel berpengaruh secara parsial terhadap loyalitas pelanggan. Secara signifikan variabel feel juga berpengaruh terhadap loyalitas pelanggan karena nilai sig lebih kecil dari $0,05(0,000<0,05)$. Sehingga dapat disimpulkan bahwa variabel feel berpengaruh secara parsial dan signifikan terhadap loyalitas pelanggan.

3. Nilai $t_{\text {hitung }}$ variabel think yaitu 11,090 dan $t_{\text {tabel }}$ bernilai 1,661 sehingga $t_{\text {hitung }}>t_{\text {tabel }}$ ( $11,090 \quad>1,661)$. Ini menunjukkan bahwa hipotesis diterima yaitu variabel think berpengaruh secara parsial terhadap loyalitas pelanggan. Secara signifikan variabel think juga berpengaruh terhadap loyalitas pelanggan karena nilai sig lebih kecil dari 0,05 ( $0,000<0,05)$. Sehingga dapat disimpulkan bahwa variabel think berpengaruh secara parsial dan signifikan terhadap loyalitas pelanggan.

4. Nilai thitung variabel act yaitu 2,606 dan $t_{\text {tabel }}$ bernilai 1,661 sehingga $t_{\text {hitung }}>t_{\text {tabel }}(2,606$ $>1,661)$. Ini menunjukkan bahwa hipotesis diterima yaitu variabel act berpengaruh secara parsial terhadap loyalitas pelanggan. Secara signifikan variabel act tidak berpengaruh terhadap loyalitas pelanggan karena nilai sig lebih besar dari 0,05 $(0,011>0,05)$. Sehingga dapat disimpulkan bahwa variabel act berpengaruh secara parsial tetapi tidak signifikan terhadap loyalitas pelanggan.

5. Nilai $t_{\text {hitung }}$ variabel relate yaitu 1,788 dan $t_{\text {tabel }}$ bernilai 1,661 sehingga $t_{\text {hitung }}>t_{\text {tabel }}($ $3,091>1,661)$. Ini menunjukkan bahwa hipotesis diterima yaitu variabel relate berpengaruh secara parsial terhadap loyalitas pelanggan. Secara signifikan variabel relate tidak berpengaruh terhadap loyalitas pelanggan karena nilai sig lebih besar dari 0,05 $(0,077>0,05)$. Sehingga dapat disimpulkan bahwa variabel relate berpengaruh secara parsial tetapi tidak 
signifikan terhadap loyalitas pelanggan.

\section{Uji F (Simultan)}

Uji F (Simultan) dilakukan untu melihat secara bersama-sama (serentak) pengaruh yang signifikan dari variabel bebas (X) yaitu sense, feel, think, act, dan relate terhadap variabel terikat $(\mathrm{Y})$ yaitu loyalitas pelanggan. Berdasarkan hasil uji statisitik (uji Anova / uji F) dapat dilihat pada tabel berikut :

\section{Tabel 2. Hasil Uji F}

\begin{tabular}{|c|c|c|c|c|c|c|}
\hline \multicolumn{2}{|c|}{ Model } & $\begin{array}{l}\text { Sum of } \\
\text { Squares }\end{array}$ & df & $\begin{array}{l}\text { Mean } \\
\text { Square }\end{array}$ & $\mathrm{F}$ & Sig. \\
\hline \multirow[t]{3}{*}{1} & Regression & 857,058 & 5 & 171,412 & 124,512 &, $000^{a}$ \\
\hline & Residual & 123,900 & 90 & 1,377 & & \\
\hline & Total & 980,958 & 95 & & & \\
\hline
\end{tabular}

a. Predictors: (Constant), relate, act, feel, sense, think

b. Dependent Variable: loyalitas

Sumber : hasil pengolahan spss

Pada tabel diatas diperoleh bahwa nilai $F$ sebesar 124,512 dengan probability $(0,000<0,05)$. Setelah mengetahui besarnya $F_{\text {hitung, maka }}$ akan dibandingkan dengan $F_{\text {tabel. }}$ Adapun hasil $F_{\text {tabel }}$ yang akan diperoleh dengan $\mathrm{df}=2$ dan $\mathrm{df} 2=96$ $-2-1=93$ dan taraf kesalahan 5\% adalah 3,09. Maka $F_{\text {hitung }}>F_{\text {tabel }}$ $(124,512>3,09)$. Dengan demikian dapat ditarik kesimpulan bahwa hipotesis dalam penelitian ini diterima pada taraf kepercayaan $95 \%$ atau $\alpha=5 \%$.

\section{Uji Determinasi $\left(\mathbf{R}^{2}\right)$}

Analisis determinasi $\left(\mathrm{R}^{2}\right)$ digunakan untuk mengukur besarnya kontribusi persentase sumbangan variabel bebas sense, fell, think, act, dan relate $\left(\mathrm{X}_{1}, \mathrm{X}_{2}, \mathrm{X}_{3}, \mathrm{X}_{4}, \mathrm{X}_{5}\right)$ terhadap variabel terikat yaitu loyalitas pelanggan (Y) secara bersama-sama dimana $0 \leq \mathrm{R}^{2} \leq 1$. Hal ini berarti nilai $R^{2}$ adalah 1 atau mendekati. Maka semakin kuat pengaruh variabel bebas terhadap variabel terikat. Sebaliknya, apabila nilai $\mathrm{R}^{2}$ mendekati 0 , maka lemah pengaruh variabel bebas terhadap variabel terikat.

Tabel 3. Hasil pengujian R Square Model Summary ${ }^{\mathrm{b}}$

\begin{tabular}{|c|c|c|c|c|c|}
\hline & $\mathrm{R}$ & $\begin{array}{l}\text { R } \\
\text { Squa } \\
\text { re }\end{array}$ & $\begin{array}{l}\text { Adjust } \\
\text { ed } \quad R \\
\text { Square }\end{array}$ & $\begin{array}{l}\text { Std. } \\
\text { Error } \\
\text { of the } \\
\text { Estima } \\
\text { te }\end{array}$ & $\begin{array}{l}\text { Durbi } \\
n- \\
\text { Wats } \\
\text { on }\end{array}$ \\
\hline 1 & $\begin{array}{l}, 93 \\
5^{a}\end{array}$ & ,874 & ,867 & 1,173 & 1,941 \\
\hline \multicolumn{6}{|c|}{$\begin{array}{l}\text { a. Predictors: (Constant), relate, act, feel, } \\
\text { sense, think } \\
\text { b. Dependent Variable: loyalitas } \\
\text { Sumber : Hasil Pengolahan spss }\end{array}$} \\
\hline \multicolumn{6}{|c|}{ bahwa koefisien determinasi $\mathrm{R}$} \\
\hline \multicolumn{6}{|c|}{$\begin{array}{l}\text { Square adalah sebesar } 0,874 \text {. Nilai } \\
\text { sebesar } 0,874 \text { ini menunjukkan bahwa } \\
\text { variabel loyalitas (Y) dapat dijelaskan } \\
\text { oleh kelima variabel (X) sense, feel, } \\
\text { think, act, dan relate sebesar } 87,4 \%\end{array}$} \\
\hline
\end{tabular}


oleh faktor-faktor lain yang tidak diteliti dalam penelitian ini.

\section{Pembahasan Hasil Penelitian}

Pengalaman yang dirasakan konsumen memiliki hubungan yang erat terhadap loyalitas pelanggan, karena pengalaman yang dirasakan konsumen akan menentukan seberapa besar loyalitas yang akan diberikan kepada perusahaan. Untuk itu perusahaan harus menciptakan pengalaman yang unik yang memberikan kesan mendalam kepada konsumen, sehingga konsumen akan melakukan pembelian kembali terhadap produk perusahaan.

Berdasarkan hasil penelitian yang dilakukan dengan angket menunjukkan bahwa 96 responden memberikan tanggapan sangat baik terhadap kelima variabel $\mathrm{X}$ yang termasuk dalam experiential marketing yaitu sense, feel, think, act, dan relate. Begitu juga dengan loyalitas pelanggan menunjukkan tanggapan sangat baik pada Waroeng Steak and Shake Cabang Sisingamangaraja Medan.

Berdasarkan hasil analisis data penelitian dapat diperoleh bahwa variabel yang termasuk dalam experiential marketing yaitu sense, feel, think, act, dan relate mempunyai pengaruh positif terhadap loyalitas pelanggan. Dari hasil analisis regresi linear berganda dari persamaan $\mathrm{Y}=$ $7,276+0,366 \mathrm{X}_{1}+0,350 \mathrm{X}_{2}+$ $0,722 X_{3}+0,201 X_{4}+0,165 X_{5}+$ e. Persamaan ini menunjukkan bahwa variabel sense sebesar 0,366, feel sebesar 0,350, think sebesar 0,722, act sebesar 0,201, dan relate sebesar 0,165 , Ini menunjukkan bahwa setiap terjadi perubahan variabel dalam experiential marketing yaitu sense
$\left(\mathrm{X}_{1}\right)$, feel $\left(\mathrm{X}_{2}\right)$, think $\left(\mathrm{X}_{3}\right)$, act $\left(\mathrm{X}_{4}\right)$, dan relate $\left(\mathrm{X}_{5}\right)$ sebesar satu satuan maka akan mempengaruhi loyalitas sebesar satu satuan variabel dalam experiential marketing (asumsi faktor lain konstan).

Berdasarkan hasil dari uji hipotesis yaitu uji $\mathrm{t}$ (parsial) diketahui bahwa variabel bebas dalam experiential marketing yaitu sense, feel, think, act, dan relate berpengaruh secara parsial terhadap loyalitas pelanggan. Hasil menunjukkan bahwa $t_{\text {hitung }}$ dari kelima variabel experiential marketing lebih besar dari $t_{\text {tabel. }}$ Nilai $t_{\text {hitung }}$ menunjukkan variabel sense sebesar 4, 146, feel sebesar 4,344, think sebesar 11,090, act sebesar 2,606, dan relate sebesar 1,788, sedangkan $t_{\text {tabel }}$ sebesar 1,661. Sehingga dapat disimpulkan kelima variabel berpengaruh secara parsial. Tetapi secara signifikan hanya variabel sense, feel, dan think yang berpengaruh sedangkan variabel act dan relate tidak berpengaruh secara signifikan. Ini sejalan dengan penelitian yang dilakukan oleh Jatmiko bahwa act dan relate berpengaruh secara parsial tetapi tidak signifikan terhadap loyalitas pelanggan.

Kelima variabel yang termasuk dalam experiential marketing, variabel think $\left(\mathrm{X}_{3}\right)$ yang paling berpengaruh terhadap loyalitas pelanggan Waroeng Steak and Shake Cabang Sisingamangaraja Medan. Variabel berikutnya yang memiliki peranan kedua yang mempengaruhi loyalitas pelanggan yaitu variabel feel $\left(\mathrm{X}_{2}\right)$, selanjutnya variabel sense $\left(\mathrm{X}_{1}\right)$. Variabel keempat yang berpengaruh terhadap loyalitas yaitu variabel act $\left(\mathrm{X}_{4}\right)$, selanjutnya variabel relate $\left(\mathrm{X}_{5}\right)$. 
Seperti yang dikatakan Kustini jika faktor penentu dari experiential marketing yaitu sense, feel, think, act, dan relate tinggi maka loyalitas pelanggan.

Hasil uji $\mathrm{F}$ sebesar 124,512 yaitu $\mathrm{F}_{\text {hitung }}>\mathrm{F}_{\text {tabel }} \quad(124,512>3,09)$, sehingga secara simultan atau serempak variabel yang termasuk dalam experiential marketing yaitu sense, feel, think, act, dan relate secara bersama-sama mempengaruhi variabel loyalitas pelanggan.

Hasil uji determinasi R Square menunjukkan bahwa variabel yang termasuk dalam experiential marketing mempengaruhi loyalitas pelanggan Waroeng Steak and Shake Cabang Sisingamangaraja Medan sebesar 87,4 \%, dan sisanya dipengaruhi oleh faktor-faktor lain yang tidak diteliti.

\section{PENUTUP}

Berdasarkan hasil pembahasan penelitian maka dapat disimpulkan, yaitu :

1. Berdasarkan hasil uji regresi berganda dari persamaan $\mathrm{Y}=$ $7,276+0,366 \mathrm{X}_{1}+0,350 \mathrm{X}_{2}+$ $0,722 X_{3}+0,201 X_{4}+0,165 X_{5}$ + e menunjukkan nilai yang positif terhadap kelima variabel dalam experiential marketing. Ini menunjukkan bahwa setiap terjadi peningkatan variabel dalam experiential marketing yaitu sense, feel, think, act, dan relate sebesar satu satuan maka loyalitas pelanggan meningkat pada Waroeng Steak and Shake Cabang Sisingamangaraja Medan.

2. Berdasarkan hasil uji t diketahui bahwa variabel sense berpengaruh secara parsial dan signifikan terhadap loyalitas pelanggan Waroeng Steak and Shake Cabang Sisingamangaraja Medan sebesar 4,146 dengan signifikan dibawah 0,05 yaitu 0,000 .

3. Berdasarkan hasil uji t diketahui bahwa variabel feel berpengaruh secara parsial dan signifikan terhadap loyalitas pelanggan Waroeng Steak and Shake Cabang Sisingamangaraja Medan sebesar 4,344 dengan signifikan dibawah 0,05 yaitu 0,000 .

4. Berdasarkan hasil uji t diketahui bahwa variabel think berpengaruh secara parsial dan signifikan terhadap loyalitas pelanggan Waroeng Steak and Shake Cabang Sisingamangaraja Medan sebesar 11,090 dengan signifikan dibawah 0,05 yaitu 0,000 .

5. Berdasarkan hasil uji t diketahui bahwa variabel act berpengaruh secara parsial tetapi tidak signifikan terhadap loyalitas pelanggan Waroeng Steak and Shake Cabang Sisingamangaraja Medan dengan pengaruh sebesar 2,606 dengan signifikan diatas 0,05 yaitu 0,011 .

6. Berdasarkan hasil uji t diketahui bahwa variabel relate berpengaruh secara parsial tetapi tidak signifikan terhadap loyalitas pelanggan Waroeng Steak and Shake Cabang Sisingamangaraja Medan dengan pengaruh sebesar 1,788 dengan signifikan diatas 0,05 yaitu 0,077 . 
7. Berdasarkan hasil uji $\mathrm{F}$ sebesar 124,512 yaitu $F_{\text {hitung }}>F_{\text {tabel }}$ $(124,512>3,09)$, sehingga secara simultan atau serempak variabel yang termasuk dalam experiential marketing yaitu sense, feel, think, act, dan relate secara bersama-sama mempengaruhi loyalitas pelanggan Waroeng Steak and Shake Cabang

Sisingamangaraja Medan.

8. Dari kelima variabel yang termasuk dalam experiential marketing yaitu sense, feel, think, act, dan relate, variabel think yang berpengaruh paling besar diantara keempat variabel lainnya. Sedangkan relate berpengaruh paling kecil diantara kelima variabel dalam experiential marketing.

9. R Square menyatakan bahwa sebesar $87,4 \%$ variabel yang termasuk dalam experiential marketing yaitu sense, feel, think, act, dan relate, berpengaruh secara bersamasama terhadap loyalitas pelanggan Waroeng Steak and Shake Cabang Sisingamangaraja Medan.

\section{DAFTAR PUSTAKA}

Andreani, Fransisca. Experiential Marketing (Sebuah Pendekatan Pemasaran). Jurnal Manajemen Pemasaran, Vol 2, No.1, April 2007: $1-8$

Bramson. 2005. Faktor dan Model Loyalitas Konsumen. Jakarta: Gramedia Pustaka Utama.

Ghojali, Imam. 2005. Analisis Multivariate Lanjutan Dengan Program SPSS. Semarang:
Badan Penerbit Universitas Diponegoro

Griffin, Jill. 2005. Customer Loyalty:Menumbuhkan dan Mempertahankan Kesetiaan Pelanggan. Jakarta: Penerbit Erlangga

Hamzah, Amir. 2007. Analisis Experiential Marketing,

Emotional Branding, dan Brand Trust terhadap Loyalitas Merek Mentari. Manajemen Usahawan Indonesia (MUI) : No.06 / Th.36 / Juni 2007, Hal.22-28

Handal. S. Nehemia. 2010. Analisis Pengaruh Experiential Marketing Terhadap Loyalitas Pelanggan (Studi Kasus: Waroeng Spesial Sambal Cab. Sompok Semarang). Skripsi Universitas Diponegoro Semarang.

Indriani, Farida. 2006. Experintial Marketing Sebagai Suatu Strategi dalam Menciptakan Customer Satisfaction dan Repeat Buying untuk Meningkatkan Kinerja Pemasaran. Jurnal Manajemen dan Organisasi, Volume 3, Nomor 1, Januari, Tahun 2006, Halaman 28-39

Irianto, Agus. 2009. Statistik Konsep Dasar dan Aplikasinya. Jakarta: Kencana

Jatmiko. 2012. Analisis Experiential Marketing dan Loyalitas Pelanggan Jasa Wisata (Studi pada Taman Rekreasi Sengkaling Malang). Jurnal Manajemen dan Kewirausahaan, Vol.14, No.2, September 2012: 128-137

Kartajaya, Hermawan. 2006. Hermawan Kertajaya on 
JURNAL PLANS

Penelitian Ilmu Manajemen \& Bisnis

ISSN: 1978-7057

Marketing. Jakarta: Gramedia Pustaka Utama

2004. Marketing in Venus.

Jakarta: Gramedia Pustaka Utama

Kustini. 2007. Penerapan

Experiential Marketing. Jurnal Riset Ekonomi dan Bisnis, Vol. 7, No.2, September 2007: 44-57

Kusumawati, Andriani. 2011. Analisis pengaruh experiential marketing terhadap kepuasan pelanggan dan loyalitas pelanggan : kasus hypermart malang town square (MATOS). Jurnal manajemen pemasaran modern, vol. 3 nomor 1 Januari - Juni 2011. ISSN 2085-0972 